\title{
Analisis pengaruh kualitas layanan, corporate image, dan customer relationship management terhadap loyalitas nasabah dengan kepuasan nasabah sebagai variabel intervening
}

\author{
Krisna Issri Kuswandarini ${ }^{1, *}$, Arna Asna Annisa ${ }^{1}$ \\ ${ }^{1}$ Fakultas Ekonomi dan Bisnis Islam IAIN Salatiga, Indonesia \\ ${ }^{*}$ Korespondensi (e-mail: krisna.x9@gmail.com)
}

\begin{abstract}
This study aims to determine and analyze the influence of service quality, corporate image, and customer relationship man agement (CRM) on customer loyalty with customer satisfaction as an intervening variable (study at Bank Syariah Indonesia branch office Semarang). This research is a quantitative research using primary data. The analysis method uses a path analysis approach. The test results show that service quality, customer relationship management, and satisfaction positively affect loyalty. The corporate image does not affect loyalty. Service quality and corporate image have no positive effect on satisfaction. Customer relationship management has a positive effect on satisfaction. Path analysis test shows that the satisfaction variable acts as a mediation between the influence of service quality, corpo rate image, customer relationship management on customer loyalty at bank BSI branch office Semarang.
\end{abstract}

Keywords: Service Quality, Corporate Image, Customer Relationship Management (Crm), Loyalty, satisfaction, Bank Syariah Indonesia KC Semarang.

\begin{abstract}
Abstrak
Penelitian ini bertujuan untuk men getahui dan menganalisis pengaruh kualitas pelayanan, citra perusahaan, dan customer relationship management (CRM) terhadap loyalitas nasabah dengan kepuasan nasabah sebagai variabel in tervening (studi pada Bank Syariah In donesia kantor cabang Semarang). Penelitian ini merupakan penelitian kuantitatif dengan menggunakan data primer. Metode analisis menggunakan pendekatan analisis jalur. Hasil pengujian menunjukkan bahwa kualitas layanan, manajemen hubungan pelanggan, dan kepuasan berpengaruh positif terhadap loyalitas. Citra perusahaan tidak mempengaruhi loyalitas. Kualitas pelayanan dan citra perusahaan tidak berpengaruh positif terhadap kepuasan. Manajemen hubungan pelanggan berpengaruh positif terhadap kepuasan. Uji analisis jalur menunjukkan bahwa variabel kepuasan berperan sebagai mediasi antara pengaruh kualitas pelayanan, citra perusahaan, manajemen hubungan nasabah terhadap loyalitas nasabah pada bank BSI kantor cabang Semarang.

Kata kunci: Kualitas Layanan, Corporate Image, Customer Relationship Management (Crm), Loyalitas, Kepuasan, Bank Rakyat In donesia Syariah KC Semarang.

How to cite: Kuswandarini, K. I., \& Annisa, A. A. (2021). Analisis pengaruh kualitas layanan, corporate image, dan customer relationship management terhadap loyal itas nasabah dengan kepuasan nasabah sebagai variabel intervening. Journal of Management and Digital Business, 1(1), 37-51.
\end{abstract}




\section{Pendahuluan}

Pada era globalisasi seperti sekarang ini, kebutuhan masyarakat menjadi semakin komplek yang mana mendorong pola pikir masyarakat supaya lebih selektif dan kritis dalam menentukan pemilihan setiap produk yang ditawarkan oleh perusahaan khususnya pada industri perbankan. Dengan adanya dorongan dari kebutuhan masyarakat membuat beberapa industri sektor perbankan bersaing, salah satunya dapat dilihat dari peningkatan jumlah kantor Lembaga Keuangan Syariah (LKS) dani tahun ke tahun. Otoritas Jasa Keuangan (OJK) menunjukkanjumlah kantor bank yang melakukan kegiatan usaha berdasarkan prinsip syariah mengalami peningkatan yang signifikan setiap tahunnya. Perbankan syariah di Indonesia tergolong jenis industri keuangan terkini dengan daya tarik yang lumayan besar, perihal ini terlihat dari banyaknya peserta baru yang mulai berkecimpung, tidak hanya dalam wujud BUS serta BPRS namun juga dalam wujud UUS (Haryono, Hilman, \& Mughits, 2003). Berikut penjelasan secara detail mengenai perkembangan kelembagaan perbankan syariah di Indonesia.

Tabel 1. Perkembangan Lembaga Perbankan Syariah di Indonesia Period

\begin{tabular}{|c|c|c|c|c|c|c|}
\hline \multirow[t]{2}{*}{ No. } & \multirow[t]{2}{*}{ Indikator } & \multicolumn{5}{|c|}{ Periode } \\
\hline & & 2015 & 2016 & 2017 & 2018 & 2019 \\
\hline \multirow[t]{4}{*}{1.} & BUS & & & & & \\
\hline & a. Total Aset & 213.423 & 254.184 & 288.027 & 316.691 & 350.364 \\
\hline & b. Jumlah Bank & 12 & 13 & 13 & 14 & 14 \\
\hline & $\begin{array}{l}\text { c. Jumlah Kantor } \\
\text { UUS }\end{array}$ & 1.990 & 1.869 & 1.825 & 1.875 & 1.919 \\
\hline \multirow{3}{*}{2.} & a. Total Aset & 82.839 & 102.320 & 136.154 & 160.636 & 174.200 \\
\hline & $\begin{array}{l}\text { b. Jumlah Bank } \\
\text { Konvensional } \\
\text { yang memiliki } \\
\text { UUS }\end{array}$ & 22 & 21 & 21 & 20 & 20 \\
\hline & $\begin{array}{l}\text { c. Jumlah Kantor } \\
\text { UUS }\end{array}$ & 311 & 332 & 344 & 354 & 381 \\
\hline \multirow[t]{3}{*}{3.} & BPRS & & & & & \\
\hline & a. Jumlah Bank & 163 & 166 & 167 & 167 & 164 \\
\hline & b. Jumlah Kantor & 446 & 453 & 441 & 495 & 617 \\
\hline
\end{tabular}

Sumber: Statistik Perbankan Syariah-Desember, 2019

Dengan adanya persaingan tersebut perbankan syariah harus memperbanui kualitas produk maupun jasanya. Demi membangun korelasi yang baik dengan masyarakat melalui program yang di selenggarakan oleh pihak bank dan dapat membantu bank tumbuh secara berkelanjutan melalui peningkatan kualitas service. Mengingat bahwa sulitnya mendapatkan nasabah yang loyal, maka dari itu untuk menjaga hal tersebut perusahaan dituntut untuk bisa mem pertahankan nasabah yang loyal. Perusahaan harus memberikan penghargaan kepada nasabahnya yang setia terhadap perusahaannya, dengan cara memberikan layanan yang terbaik. Namun, jika banyak nasabah setia yang lepas dari perusahaan maka perusahaanakan mengalami kerugian. Hal ini menyebabkan juga perusahaan akan mengeluarkan biaya yang banyak untuk mendapatkan nasabah yang loyal, beberapa faktor yang dapat 
menyebabkan hal tersebut terjadi diantaranya adalah kualitas layanan, manajemen hubungan nasabah yang lebih baik dan lain sebagainya.

Usaha berikutnya yang dapat diperbuat oleh perusahaan dalam rangka menaikkan tingkat loyalitas nasabah ialah dengan cara membuat citra perusahaan yang positif pada benak nasabah. Citra perusahaan merupakan penilaian nasabah untuk suatu perusahaan. Menurut Yudiana \& Setyono, (2016) citra perusahaan yang baik sangat penting untuk keberlangsungan hidup perusahaan, karena akan mempenganuhi semua elemen yang ada di dalam perusahaan. Perusahaan atau bank yang dapat membangun citra yang baik diantara nasabah akan memungkinkan nasabahnya untuk tetap percaya dan loyal kepada bank.

Bank syariah dengan lembaga keuangan lainnya saling berlomba memberi beragam layanan menarik untuk memenangkan persaingan. Menjaga loyalitas pelanggan dengan membangun hubungan yang baik merupakan langkah awal untuk mengatasi persaingan yang sulit ini. Menurut pandangan Suwitho (2014) untuk memperoleh nasabah yang setia, salah satu cara perusahaan adalah dengan menerapkan CRM (Customer Relationship Management). Konsep penerapan CRM berbeda dari asumsi bahwa pelanggan lebih suka memelihara hubungan jangka panjang yang baik dengan satu organisasi daripada berpindah antar organisasi. Lalu biaya untuk mendapatkan nasabah 6-7 kali lebih tinggi daripada biaya mempertahankan nasabah yang sudah ada (Komalasari, 2015).

\section{Tinjauan Pustaka}

Menurut Rhenald (2003) citra perusahaan yang baik dimaksudkan supaya perusahaan dapat senantiasa hidup dan orang-orang yang bersds didalamnya terus dapat meningkatkan kreativitasnya bahkan dapat memberikan manfaat lebih untuk orang lain, sedangkan citra perusahaan adalah kesan psikologis dan cerminan dari bermacam aktivitas perusahaan di mata khalayak publik bersumber pada pengetahuan, asumsi dan pengalaman yang sudah diterimanya.

Customer Relationship Management (CRM) merupakan kegiatan yang memungkinkan bank mengelola hubungan dengan nasabah. Kemudian, dalam menjalankan aktivitas tersebut, bank dapat mengetahui kebutuhan nasabah. Berdasarkan berbagai definisi diatas, dapat disimpulkan bahwa CRM merupakan strategi bisnis jangka panjang perusahaan yang bertujuan untuk memperoleh dan memelihara hubungan dengan dukungan data pelanggan dan teknologi perusahaan, serta tetap berhubungan baik dengan pelanggan potensial.

Loyalitas pelanggan merupakan sikap setia pelanggan yang dapat dilihat dari aktivitas mereka dalam melakukan transaksi yang dilakukan secara terus menerus mereka lakukan atas produk atau jasa, lalu juga dapat dibuktikan dengan sikap positf yaitu seperti merekomendasikan orang lain untuk membeli atau memakai produk atau jasa pada bank. 
Menurut Kotler et al., (2012) bagi seseorang kepuasan adalah suatu kesenangan atau kekecewaan yang bermula dari perbandingan antara kesan dan harapannya terhadap hasil kinerja menyatakan bahwa kepuasan dalah perasaan senang atau kecewa sesorang yang berasal dari perbandingan antara kesannya terhadap hasil kinerja produk atau jasanya. Sementara kulaitas pelayanan ialah tingkatan seberapa jauh perbandingan antara kenyatan di lapangan serta harapan konsumen atas layanan yang mereka dapatkan.

\section{Metode Penelitian}

Penelitian ini adalah penelitian dengan menggunakan metode kuantitatif. Metode Kuantitatif merupakan metode penelitian yang menggunakan angka atau analisis data numerik (Suryani \& Hendriyadi, 2016). Disini yang akan penulis teliti adalah nasabah yang ada di Bank Syariah Indonesia (BSI) KC Semarang. Jika dilihat dari segi sifatnya, penelitian ini bersifat analisis deskritif, yaitu penelitian yang memaparkan data yang diperoleh secara langsung, kemudian akan dilakukan analisis menggunakan pendekatan landasan teori yang sudah ada sebagai acuan analisisnya.

Sedangkan Sampel merupakan sebagian dari populasi penelitian dan dipilih untuk mewakili seluruh populasi (Bawono, 2006). Penelitian ini menggunakan teknik purposive sampling untuk pengambilan sampel. Purposive Sampling merupakan teknik pengambilan sampel yang tidak didasarkan pada strata atau random sam pling, tetapi berdasarkan pertimbangan untuk tujuan tertentu. Karena tidak diketahui berapa besar jumlah populasi dalam penelitian inidan itu merupakan kerahasiaan suatu Bank, maka menggunakan rumus Wibisono dalam (Riduwan \& Akdon, 2013) yang akan digunakan untuk menentukan besarnya sampel pada penelitian ini adalah sebagai berikut:

$N=\left(\frac{\left(\frac{Z a}{2} \cdot \sigma\right)}{e}\right)^{2}=\left(\frac{(1,96 \cdot 0,25}{5 \%}\right)^{2}=96,04$

$\mathrm{N}=96,04$ dibulatkan menjadi 100

Keterangan:

$\mathrm{N} \quad=$ Jumlah Sampel

$\mathrm{Za} / 2=$ Nilai yang didapat dari tabel normalitas tingkat keyakinan $95 \%=1,96$

$\sigma \quad=$ standar deviasi $25 \%$

e $\quad=\operatorname{error}($ batas kesalahan $=5 \%)$

Berdasarkan perhitungan di atas terlhat bahwa sampel yang tersedia dan dapat digunakan sebanyak 96 responden, namun penulis membulatkan sampel tersebut menjadi 100 responden Bank Syariah Indonesia (BSI) KC Semarang.

Untuk menguji pengaruh variabel intervening digunakan metode anlisis jalur (Path Analysis). Analisis merupakan perluasan dari analisis regresi linier berganda, atau dapat diartikan sebagai penggunaan analisis regresi untuk menaksir hubungan 
kausalitas antara variabel kausal yang ditetapkan sebelumnya berdasarkan teori (Ghozali, 2018). Adapaun persamaan model penelitian sebagai berikut.

Persamaan 1: Loy $=\beta_{0}+\beta_{1}$ kualLay $+\beta_{2}$ CorpImage $+\beta_{3}$ CRM $+\beta_{4}$ KepNas $+e$

Persamaan 2: KepNas $=\beta_{0}+\beta_{1}$ kualLay $+\beta_{2}$ CorpImage $+\beta_{3} C R M+e$

\section{Hasil dan Pembahasan}

\subsection{Hasil penelitian}

\section{Uji Multikolonieritas}

Untuk uji multikolonieritas pada penelitian ini, peneliti menggunakan metode Varian Inflation Factor (VIF) tidak boleh lebih dari 10 dan nilai Toleransi lebih dari 0,10.

Tabel 2. Hasil Uji Multikolinearitas

\begin{tabular}{lrrrrrr}
\hline Model $^{\mathrm{a}}$ & koefisien & Std. Error & $\mathrm{t}$ & \multicolumn{2}{l}{ Sig. } & \multicolumn{2}{l}{ Tolerance VIF } \\
\hline (Constant) $_{\text {Kualitas Layanan }}^{5,783}$ & 4,356 & 1,328 & 0,187 & & \\
Corporate Image & 0,162 & 0,084 & 1,626 & 0,000 & 0,565 & 1,769 \\
CRM & 0,102 & 0,109 & 1,478 & 0,143 & 0,819 & 1,221 \\
Kepuasan Nasabah & 0,231 & 0,133 & 2,741 & 0,004 & 0,529 & 1,889 \\
\hline
\end{tabular}

a. Dependent Variable:Loyalitas Nasabah

Berdasarkan Tabel 2, memperlihatkan bahwa nilai VIF $<10$ dan nilai toleran $>0,10$ maka penelitian ini bebas dari masalah multikolonieritas.

\section{Uji Heteroskedastisitas}

Uji Heteroskedastisitas untuk menguji apakah terdapat ketidaksamaan variance dan residual atau observasi terkait dengan observasi lain dalam model regresi. Jika variance dan residual antara satu pengamatan ke pengamatan lain konstan maka disebut Hemoskedasitisitas dan jika hasilnya berbeda disebut dengan Heteroskedastisitas. Untuk mengetahui ada tidaknya gejala Heteroskedasitas, beberapa metode dapat digunakan, salah satunya yaitu metode park.

Tabel 3. Hasil Uji Heteroskedastisitas

\begin{tabular}{lcccc}
\hline Model & Koefisien & Std. Error & $\mathrm{t}$ & Sig. \\
\hline (Constant) & 5,783 & 4,356 & 1,328 & 0,090 \\
Kualitas Layanan & 0,162 & 0,084 & 1,626 & 0,056 \\
Corporate Image & 0,102 & 0,109 & 1,478 & 0,239 \\
CRM & 0,231 & 0,133 & 2,741 & 0,521 \\
Kepuasan Nasabah & 0,468 & 0,148 & 3,172 & 0,481 \\
\hline
\end{tabular}

a. Dependent Variable:RES2

Dari data di atas menunjukkan nilaisignifikan $>0,05$ maka pada penelitian ini model regresi tidak terjadi adanya heteroskedastisitas.

\section{Uji Normalitas}

Tabel 4. One-Sample Kolmogorov-Smirnov Test

\begin{tabular}{|c|c|c|}
\hline & & Unstandardized Residual \\
\hline$\overline{\mathrm{N}}$ & & 100 \\
\hline Normal & Mean & 0,0000000 \\
\hline Parameters ${ }^{a, b}$ & Std. Deviation & 2,07066965 \\
\hline
\end{tabular}




\begin{tabular}{llr}
\hline Most Extreme & Absolute & 0,066 \\
Differences & Positive & 0,064 \\
& Negative & $-0,066$ \\
Test Statistic & & 0,066 \\
Asymp.Sig. (2-tailed) & $0,200^{\mathrm{c}, \mathrm{d}}$ \\
\hline
\end{tabular}

a. Test distribution is Normal.

b. Calculated from data.

Dalam pengujian ini peneliti menggunakan analisis statistik, dan data yang dapat digunakan untuk menguji normalitas residual yaitu uji statistik non parametrik Kolomongorov-Smirnov. Dari Tabel 4, didapat nilai signifikan sebesar 0,082 yang berarti normal dari nilai Asymp. Sig diatas 0,05 (p-values). Hal tersebut menunjukkan bahwa model data berdistribusi normal dan asumsi normalitasnya terpenuhi.

\section{Uji Linieritas}

Uji Linieritas digunakan untuk menguji data, apakah spesifikasi model yang digunakan sudah benar atau lebih baik menggunakan mode lain (linier, kuadrat atau kubik). Metode yang digunakan dalam penelitian ini adalah metode Engle Lagrange Multiplier (ELM). Hasilnya menunjukkan bahwa Variabel Kualitas Layanan bernilai 0,057 >0,05, Variabel Corporate Image bernilai 0,454 > 0,05, Variabel CRM bernilai 0,085 >0,05, Variabel Kepuasan Nasabah bernilai 0,063 $>0,05$, sehingga dapat diartikan ada hubungan linier antara kepuasan terhadap Loyalitas.

\section{Uji Koefisien Determinan ( $\mathbf{R}^{2}$ )}

Koefisien Determinasi $\left(R^{2}\right)$ pada dasarnya adalah kisaran yang mengukur kemampuan model untuk menjelaskan perubahan variabel dependen. Nilai koefisien determinasi berada di antara nol dan satu. Nilai $\left(R^{2}\right)$ yang kecil berarti kemampuan variabel independen dalam menjelaskan perubahan variabel dependen sangat terbatas. Nilai yang mendekati 1 menunjukkan bahwa variabel independen menyediakan hampir semua informasi yang dibutuhkan untuk memprediksi perubabaan variabel dependen, dan koefisien digunakan untuk menguji goodnessfit dari model regresi. Hasil dari uji data penelitian bahwa selu ruh variabel secara bersama- sama bernilai m endekati satu. Hal ini berarti ada hubungan yang cukup kuat antara variabel independen dengan dependen.

\section{Uji Signifikansi Simultan (F Test)}

Uji Statistik $F$ pada dasarnya menunjukkan bahwa semua variabel bebas atau independen yang dimasukkan ke dalam model, mempunyai pengaruh yang sama terhadap variabel dependen. Dasar pengambilan keputusan dalam uji ini adalah sebagai berikut: Jika $F$ hitung $<F$ tabel, maka Ho diterima artinya adanya penganuh yang signifikan antara variabel independen secara bersamaan terhadap variabel dependen dan sebaliknya. Selain itu, dengan membandingkan $F$ hitung dengan $F$ tabel untuk menghitung $\mathrm{HO}$ dapat diterima atau tidak untuk melihat apakah nilai signifikansi lebih dari atau kurang dari $5 \%$. Hasil dari uji data penelitian bahwa seluruh variabel secara bersama-sama berpengaruh.

\section{Uji Signifikan Parameter Individual (T Test)}

Ada aturan pengambilan keputusan uji-tmenggunakan dasar pengambilan keputusan sebagai berikut: Jika $t$ hitung $<\mathrm{t}$ tabel, maka Ho diterima, yang artinya tidak ada 
pengaruh yang positif dan signifikan antara variabel independen dengan variabel dependen. Jika thitung $>t$ tabel, maka Ho ditolak yang artinya terdapst pengaruh yang positif dan signifikan antara variabel independen dengan variabel dependen.

Berdasakan hasil analisis regresi, hasil dari uji t dalam penelitian ini menunjukkan bahwa:

- Variabel Kualitas Layanan memiliki thitung sebesar 1,626, nilai koefisien sebesar 0,162 dan taraf signifikan variabel Kualitas Layanan sebesar 0,000 lebih kecil dari $0,05(5 \%)$, sehingga ada pengaruh signifikan antara variabel Kualitas Layanan terhadap Loyalitas Nasabah. Dengan demikian dapat disimpulkan bahwahipotesis 1 diterima.

- Variabel Corporate Image memiliki thitung sebesar 1,478, nilai koefisien sebesar 0,102 dan taraf signifikan variabel Corporate Image sebesar 0,143 lebih besar dari $0,05(5 \%)$, sehingga tidak ada pengaruh signifikan antara variabel Corporate Image terhadap Loyalitas Nasabah. Maka dapat disimpulkan bahwa hipotesis 2 ditolak.

- Variabel CRM memiliki t hitung sebesar 2,741 nilai koefisien sebesar 0,231 dan taraf signifikan variabel CRM sebesar 0,004 lebih kecil dari 0,05 (5\%), sehingga ada pengaruh signifikan antara variabel CRM terhadap Loyalitas Nasabah. Maka dapat disimpulkan hipotesis 3 diterima.

- Variabel Kualitas Layanan memiliki thitung sebesar 0,292, nilai koefisien sebesar 0,217 dan taraf signifikan variabel Kualitas Layanan sebesar 0,771 lebih besar dari $0,05(5 \%)$, sehingga tidak ada pengaruh signifikan antara variabel Kualitas Layanan terhadap Kepuasan Nasabah. Maka dapat disimpulkan hipotesis 4 ditolak.

- Variabel Corporate Image memiliki thitung sebesar 1,626, nilai koefisien sebesar 0,221 dan taraf signifikan variabel Corporate Image sebesar 0,107 lebih besar dari $0,05(5 \%)$, sehingga tidak ada pengaruh signifikan antara variabel Corporate Image terhadap Kepuasan Nasabah. Maka dapat disim pulkan hipotesis 5 diterima.

- Variabel CRM memiliki t hitung sebesar 3,031, nilai koefisien sebesar 0,266 dan taraf signifikan variabel CRM sebesar 0,003 lebih kecil dari 0,05 (5\%), sehingga ada pengaruh signifikan antara variabel CRM terhadap Kepuasan Nasabah. (Sari, Daryanto, \& Saptono, 2018). Maka dapat disimpulkan hipotesis 6 diterima.

- Variabel Kepuasan Nasabah sebesar 3,172, nilaikoefisien sebesar 0,468 dan taraf signifikan variabel Kepuasan Nasabahsebesar 0,002 lebih kecil dari 0,05 (5\%), sehingga ada pengaruh signifikan antara variabel Kepuasan Nasabah terhadap Loyalitas Nasabah. Maka dapat disimpulkan hipotesis 7 diterima.

- Nilai hitung sobel test sebesar 2,239 (dibulatkan) > t tabel yaitu 1,661 dengan tingkat signifikan $5 \%$, maka dapat disimpulkan bahwa signifikan. Hal ini berarti Kepuasan Nasabah mampu memediasi pengaruh Kualitas Layanan terhadap Loyalitas Nasabah. Maka dapat disimpulkan hipotesis 8 diterima.

- Nilai hitung sobel test sebesar 1,899 (dibulatkan) > dari t tabel yaitu 1,661 dengan tingkat signifikan $5 \%$, maka dapat disimpulkan bahwa signifikan. Hal ini berarti Kepuasan Nasabah mampu memediasi pengaruh Corporate Image terhadap Loyalitas Nasabah. Maka dapat disimpulkan hipotesis 9 diterima. 
- Nilai hitung sobel test sebesar 1,757 (dibulatkan) > dari t tabel yaitu 1,661 dengan tingkat signifikan 5\%, maka dapat disimpulkan bahw signifikan. Hal ini berarti Kepuasan Nasabah mampu memediasi pengaruh CRM terhadap Loyalitas Nasabah. Maka dapat disimpulkan bahwa hipotesis 10 diterima.

\subsection{Pembahasan}

Berdasakan hasil dari uji t dalam penelitian ini menunjukkan bahwa ada penganuh signifikan antara variabel Kualitas Layanan terhadap Loyalitas Nasabah. Hal ini didukung penelitian yang dilakukan oleh Yulimindra dan Samsir (2015) yang menunjukkan bahwa kualitas layanan berpengaruh positif dan signifikan terhadap loyalitas pelanggan. Perusahaan perlu menyediakan layanan berkualitas tinggi kepada pelanggan untuk meningkatkan loyalitas pelanggan.

Hasil analisis regresi menunjukkan bahwa tidak ada pengaruh signifikan antara variabel Corporate Image terhadap Loyalitas Nasabah. Hal ini berbanding terbalik dengan penelitian Apriyanti et al. (2017) yang menilai citra perbankan berdampak positif terhadap loyalitas nasabah. Hipotesis tersebut tidak diterima karena pemahaman nasabah tentang wawasan dari sudut pandang usia nasabah dan faktor pendidikan terakhir nasabah yang berbeda, sehingga mereka meyakini bahwa citra dari masing-masing bank itu sama.

Hasil analisis regresi menunjukkan bahwa ada pengaruh signifikan antara variabel CRM terhadap Loyalitas Nasabah. Hal ini didukung oleh penelitian yang dilakukan oleh Imasari dan Nursalin (2011) yang menunjukkan bahwa CRM mempengaruhi loyalitas nasabah.

Hasil analisis menunjukkan bahwa tidak ada pengaruh signifikan antara variabel Kualitas Layanan terhadap Kepuasan Nasabah. Perihal itu bebanding terbalik dengan riset yang dilakukan oleh Trisnowati (2012) yang menunjukkan bahwa kualitas layanan yang meliputi kehandalan (reliability), daya tanggap (responsiveness), jaminan (assurance), perhatian (emphaty), dan bukti fisik (tangible) secara bersama-sama berpengaruh positif dan signifikan terhadap kepuasan nasabah. Tidak diterimanya hipotesis ini nasabah belum merasa adanya kepuasan yang diberikan pihak bank karena fator nasabah merasa terburu- buru, atau mereka hanya sekedar setor tunai. Jadi tidak ada interaksi yang cukup lama untuk menilai.

Hasil analisis regresi menunjukkan bahwa variabel Corporate Image terhadap Kepuasan Nasabah. Hal ini didukung oleh penelitian yang dilakukan oleh Setyono (2015) yang menunjukkan bahwa Citra perusahaan mempunyai pengaruh yang signifikan terhadap kepuasan nasabah dan loyaitas nasabah. Penelitian lainnya oleh Mulyaningsih \& Suasana (2016) yang menyatakan hasil analisis ditemukan bahwa Citra perusahaan berpengaruh positif dan signifikan terhadap kepuasan nasabah Bank OCBC NISP di Denpasar.

Hasil analisis regresi menunjukkan bahwa ada pengaruh signifikan antara variabel CRM terhadap Kepuasan Nasabah. (Sari et al., 2018). Hal ini didukung oleh peelitian 
terdahulu yang dilakukan oleh Sari et al., (2018) yang menyatakan bahwa CRM berpengaruh positif signifikan terhadap kepuasan nasabah. Penelitian lainnya oleh Nardiman (2017) yang menjelaskan bahwa CRM berpengaruh signifikan terhadap kepuasan nasabah BankBRI unit Tiku Cabang Bukit Tinggi.

Hasil analisis regresi menunukkan bahwa ada pengaruh signifikan antara variabel Kepuasan Nasabah terhadap Loyalitas Nasabah. Hal tersebut didukung dengan penelitian yang dilakukan oleh R. Ben Saputra dan Alwie (2015) yang menunjukkan bahwa kepuasan berpengaruh positif dan signifikan terhadap loyalitas nasabah. Peneitian lain dilakukan oleh Sri rahayu etal., (2014) yang membuktikan bahwa secara simultan variabel kepercayaan dan kepuasan mempunyai pengaruh yang positif dan signifikan terhadap loyalitas nasabah. Hal ini menunjukkan bahwa semakin tinggi tingkat kepuasan maka nasabah akan semakin setia dengan perusahaan.

Hasil penelitian menunjukkan bahwa Kepuasan Nasabah mampu memediasi pengaruh Kualitas Layanan terhadap Loyalitas Nasabah. Hal ini didukung oleh penelitan yang dilakukan oleh Ishak dan Azzahroh (2017) menunjukkan bahwa Kepuasan nasabah mampu memediasi secara penuh pengaruh kualitas layanan terhadap loyalitas nasabah Bank syariah. Penelitian lain juga dilakukan oleh Lutfiana et al., (2013) yang menyatakan bahwa kualitas pelayanan berpengaruh secara langsung maupun tidak langsung terhadaployalitas melalui kepuasan nasabah $\mathrm{Hal}$ itu menegaskan bahwa semakin baik kualitas pelayanan yang diberikan maka nasabah akan merasa puas sehingga nasabah akan semakin setia dengan perusahaan.

Nilai hitung sobel test menunjukkan Kepuasan Nasabah mampu memediasi pengaruh Corporate Image terhadap Loyalitas Nasabah. Hal ini didukung penelitian yang dilakukan oleh F. I. Saputra (2013) Citra perusahaan mempunyai hubungan yang kuat dengan loyalitas pelanggan melalui kepuasan pelanggan, gambaran ini memberikan isyarat bahwa dengan kepuasan seseorang akan tetap loyal apabila cita perusahaan dengan apayang dirasakan nasabag dapat terwujud, maka akan membuat nasabah menjadi loyal.

Hasil nilai hitung sobel test menunjukkan Kepuasan Nasabah mampu memediasi pengaruh CRM terhadap Loyalitas Nasabah. Hal ini didukung oleh penelitian yang dilakukan oleh Nisazizah \& Sudaryanto (2018) menyatakan bahwa Jalur yang paling berpengaruh untuk meningkatkan loyalitas nasabah BNI Syariah adalah kualitas layanan ke kepuasan nasabah, ke loyalitas nasabah serta pengaruh langsung dari kualitas layanan ke loyalitas nasabah.

\section{Kesimpulan}

Kualitas layanan berpengaruh positif dan signifikan terhadap loyalitas nasabah, sehingga $\mathrm{H} 1$ diterima. Corporate image berpengaruh positif tetapi tidak signifikan terhadap loyalitas nasabah, sehingga $\mathrm{H} 2$ ditolak. Customer relationship management (crm) berpengaruh positif dan signifikan terhadap loyalitas nasabah, sehingga H3 diterima. Kualitas layanan berpengaruh positif tetapi tidak signifikan terhadap kepuasan nasabah, sehingga $\mathrm{H} 4$ ditolak. Corporate image berpengaruh positif tetapi 
tidak signifikan terhadap kepuasan nasabah, sehingga H5 ditolak. Customer relationship management (crm) berpengaruh positif dan signifikan terhadap kepuasan nasabah, sehingga $\mathrm{H} 6$ diterima. Kepuasan nasabah berpengaruh positif dan signifikan terhadap loyalitas nasabah, sehingga $\mathrm{H} 7$ diterima. Kualitas layanan berpenganuh positif dan signifikan terhadap loyalitas nasabah melalui kepuasan nasabah sebagai variabel intervening, sehingga $\mathrm{H} 8$ diterima. Corporate image akan berpengaruh positf dan signifikan terhadaployalitas nasabah melalui kepuasan nasabah sebagai variabel intervening, sehingga $\mathrm{H} 9$ diterima. Customer relationship management (CRM) berpengaruh positif dan signifikan terhadap loyalitas nasabah melalui kepuasan nasabah sebagai variabel intervening, sehingga $\mathrm{H} 10$ diterima.

\section{Ucapan Terimakasih}

Pertama saya ucapkan terimakash kepada almamater saya IAIN Salatiga yang memberikan wadah dan ruang untuk saya menuntut ilmui. Kepada pihak lembaga keuangan atau bankyang telah memberikan kesem patan kepada saya untuk proses pengambilan data dan pengamatan fenomena dalam menyelesaikan tugas akhir saya. Harapan saya semoga penelitian ini mampui menjadi referensi dan rujukan untuk kedepannya semoga lebih baik dan mencakup lebih luas lagi.

\section{Referensi}

Apriyanti, P., Surya, D., \& Lutfi, L. (2017). Analisis Kualitas Layanan Dan Citra Perusahaan Terhadap Loyalitas Nasabah Dengan Kepuasan Nasabah Sebagai Variabel Intervening (Studi Empirik Nasabah Tabungan Tandamata Bank BJB Cabang Serang). Jurnal Riset Bisnis Dan Manajemen Tirtayasa, 1(2).

Bawono, A. (2006). Multivariate analysis dengan SPSS. Salatiga: STAIN Salatiga Press.

Ghozali, I. (2018). Aplikasi Analisis Multivariate dengan Program IBM SPSS 25 (9th ed.). Semarang: Semarang: Badan Penerbit Universitas Diponegoro.

Goyena, R., \& Fallis, A. . (2019). Statistik Perbankan Syariah - Desember. Journal of Chemical Information and Modeling, 53(9), 1689-1699.

Haryono, S., Hilman, I., \& Mughits, A. (2003). Perbankan Syariah Masa Depan. Jakarta: Senayan Abadi Publishing.

Imasari, K., \& Nursalin, K. K. (2011). Pengaruh Customer Relationship Management terhadap Loyalitas Pelanggan pada PTBCA Tbk. Fokus Ekonomi (FE), 10(3).

Ishak, M. Z., \& Azzahroh, E. P. (2017). Pengaruh Kualitas Layanan Terhadap Loyalitas Nasabah Bank Syariah Dengan Kepuasan Nasabah Sebagai Variabel Intervening. Jurnal Ekonomi Dan Bisnis Islam (Journal of Islamic Economics and Business), 3(1). https://doi.org/10.20473/jebis.v3i1.3599

Komalasari, E. (2015). Peranan Customer Relationship Dalam Meningkatkan Loyalitas Nasabah Di PerBankan. Peranan Customer Relationship Dalam Meningkatkan Loyalitas Nasabah Di Perbankan, 9(2).

Kotler, P., Keller, \& Lane, K. (2012). Manajemen Pemasaran (Jilid 2). Jakarta: PT. Indeks. 
Lutfiana, A. A., Saryadi, S., \& Wijayanto, A. (2013). Pengaruh citra Merek dan Kualitas Produk Dengan Kepuasan Konsumen Sebagai Variabel Antara Terhadap Loyalitas Konsumen Air Minum Merek Aqua (Studi pada Konsumen Aqua yang Berdomisili di Perumahan Puri Anjasmoro). Jurnal Ilmu Administrasi Bisnis, 1(1), 61-72.

Mulyaningsih, L. A., \& Suasana, I. (2016). Pengaruh Kualitas Layanan Dan Citra Perusahaan Terhadap Kepuasan Nasabah Pada Bank Ocbc Nisp Di Denpasar. E-Jurnal Manajemen Universitas Udayana, 5(1).

Nardiman. (2017). Pengaruh Customer Relationship Management Dan Customer Value Terhadap Kepuasan Nasabah Dan Dampaknya Pada Loyalitas Nasabah Bank BRI Unit Tiku Cabang Bukittinggi. Jurnal EKOBISTEK Fakultas Ekonomi, 6(2), 251-256.

Nisazizah, B., \& Sudaryanto, B. (2018). Analisis Pengaruh Kualitas Layanan, Nilai Nasabah, dan Customer RelationshipManagement terhadap Kepuasan Nasabah Serta Loyalitas Nasabah (Studi Pada Nasabah BNI Syariah Kantor Cabang Semarang dan Kantor Cabang Pembantu UNISULA). Diponegoro Journal of Management, 7(4), 116-127.

Rhenald, K. (2003). Marketing Public Relations. Jakarta: PT Temprint.

Riduwan, \& Akdon. (2013). Rumus Dan Data Dalam Analisis Statistika. Bandung: Alphabeta.

Saputra, R. Ben, \& Alwie, A. P. (2015). Pengaruh Kualitas Pelayanan dan Kepuasan Nasabah Terhadap Loyalitas Nasabah Pada PT. Bank Riau Kepri cabang Siak. Jurnal Tepak Manajemen Bisnis, 7(2), 285-294.

Saputra, F. I. (2013). Kualitas Layanan, Citra dan Pengaruhnya terhadapLoyalitas melalui Kepuasan Pelanggan(Studi Pada PT Bank Bni 46 Sentra Kredit Kecil Surabaya). JURNAL APLIKASI MANAJEMEN, 2(3).

Sari, N. P., Daryanto, H. K., \& Saptono, I. T. (2018). Pengaruh customer relationship management terhadap kepuasan dan loyalitas nasabah PT Bank BNI. Jurnal Aplikasi Bisnis Dan Manajemen (JABM), 4(1).

Setyono, L. (2015). The effect of Islamic marketing and corporate image on customer satisfaction and customer loyalty (Study on customers of PT Bank Muamalat Indonesia Malang branch office). Jurnal Administrasi Bisnis (JAB), 27(1).

Sri rahayu, B., Saryanti, E., \& STIE Adi Unggul Bhirawa Surakarta. (2014). Pengaruh Kualitas Pelayanan, Hubungan Pelanggan Dan Citra Perusahaan Terhadap Loyalitas Melalui Kepuasan Nasabah. ADVANCE, 1(2).

Suryani, \& Hendriyadi, H. (2016). Metode riset kuantitatif: Teori dan aplikasi pada penelitian bidang manajemen dan ekonomi Islam. Prenada Media.

Suwitho, M. (2014). Pengaruh Customer Relationship Management Terhadap. Jurnal Ilmu Dan Riset Manajemen, 3.

Trisnowati, J. (2012). Pengaruh Kualitas Pelayanan Terhadap Kepuasan Nasabah Di PT. Bank Perkreditan Rakyat Kartasura Saribumi Cabang Masaran.

Yudiana, F. E., \& Setyono, J. (2016). Analisis Corporate Social Responsibility, Loyalitas Nasabah, Corporate Image dan Kepuasan Nasabah pada Perbankan Syariah. INFERENSI: Jurnal Penelitian Sosial Keagamaan, 10(1), 93-114. 
Yulimindra, I., \& Samsir, G. W. (2015). Pengaruh Kualitas Layanan dan Inovasi Terhadap Citra Perusahaan dan Loyalitas Nasaba pada PT Bank Riau Kepri. Jurnal Tepak Manajemen Bisnis, 7(3).

Apriyanti, P., Surya, D., \& Lutfi, L. (2017). Analisis Kualitas Layanan Dan Citra Perusahaan Terhadap Loyalitas Nasabah Dengan Kepuasan Nasabah Sebagai Variabel Intervening (Studi Empirik Nasabah Tabungan Tandamata Bank BJB Cabang Serang). Jurnal Riset Bisnis Dan Manajemen Tirtayasa, 1(2).

Bawono, A. (2006). Multivariate analysis dengan SPSS. Salatiga: STAIN Salatiga Press.

Ghozali, I. (2018). Aplikasi Analisis Multivariate dengan Program IBM SPSS 25 (9th ed.). Semarang: Semarang: Badan Penerbit Universitas Diponegoro.

Goyena, R., \& Fallis, A. . (2019). Statistik Perbankan Syariah - Desember. Journal of Chemical Information and Modeling, 53(9), 1689-1699.

Haryono, S., Hilman, I., \& Mughits, A. (2003). Perbankan Syariah Masa Depan. Jakarta: Senayan Abadi Publishing.

Imasari, K., \& Nursalin, K. K. (2011). Pengaruh Customer Relationship Management terhadap Loyalitas Pelanggan pada PTBCA Tbk. Fokus Ekonomi (FE), 10(3).

Ishak, M. Z., \& Azzahroh, E. P. (2017). Pengaruh Kualitas Layanan Terhadap Loyalitas Nasabah Bank Syariah Dengan Kepuasan Nasabah Sebagai Variabel Intervening Jurnal Ekonomi Dan Bisnis Islam (Journal of Islamic Economics and Business), 3(1). https://doi.org/10.20473/jebis.v3i1.3599

Komalasari, E. (2015). Peranan Customer Relationship Dalam Meningkatkan Loyalitas Nasabah Di PerBankan. Peranan Customer Relationship Dalam Meningkatkan Loyalitas Nasabah Di Perbankan, 9(2).

Kotler, P., Keller, \& Lane, K. (2012). Manajemen Pemasaran (Jilid 2). Jakarta: PT. Indeks.

Lutfiana, A. A., Saryadi, S., \& Wijayanto, A. (2013). Pengaruh citra Merek dan Kualitas Produk Dengan Kepuasan Konsumen Sebagai Variabel Antara Terhadap Loyalitas Konsumen Air Minum Merek Aqua (Studi pada Konsumen Aqua yang Berdomisili di Perumahan Puri Anjasmoro). Jurnal Ilmu Administrasi Bisnis, 1(1), 61-72.

Mulyaningsih, L. A., \& Suasana, I. (2016). Pengaruh Kualitas Layanan Dan Citra Perusahaan Terhadap Kepuasan Nasabah Pada Bank Ocbc Nisp Di Denpasar. E-Jurnal Manajemen Universitas Udayana, 5(1).

Nardiman. (2017). Pengaruh Customer Relationship Management Dan Customer Value Terhadap Kepuasan Nasabah Dan Dampaknya Pada Loyalitas Nasabah Bank BRI Unit Tiku Cabang Bukittinggi. Jurnal EKOBISTEK Fakultas Ekonomi, 6(2), 251-256.

Nisazizah, B., \& Sudaryanto, B. (2018). Analisis Pengaruh Kualitas Layanan, Nilai Nasabah, dan Customer RelationshipManagement terhadap Kepuasan Nasabah Serta Loyalitas Nasabah (Studi Pada Nasabah BNI Syariah Kantor Cabang Semarang dan Kantor Cabang Pembantu UNISULA). Diponegoro Journal of Management, 7(4), 116-127.

Rhenald, K. (2003). Marketing Public Relations. Jakarta: PT Temprint. 
Riduwan, \& Akdon. (2013). Rumus Dan Data Dalam Analisis Statistika. Bandung: Alphabeta.

Saputra, R. Ben, \& Alwie, A. P. (2015). Pengaruh Kualitas Pelayanan dan Kepuasan Nasabah Terhadap Loyalitas Nasabah Pada PT. Bank Riau Kepri cabang Siak. Jurnal Tepak Manajemen Bisnis, 7(2), 285-294.

Saputra, F. I. (2013). Kualitas Layanan, Citra dan Pengaruhnya terhadapLoyalitas melalui Kepuasan Pelanggan(Studi Pada PT Bank Bni 46 Sentra Kredit Kecil Surabaya). JURNAL APLIKASI MANAJEMEN, 2(3).

Sari, N. P., Daryanto, H. K., \& Saptono, I. T. (2018). Pengaruh customer relationship management terhadap kepuasan dan loyalitas nasabah PT Bank BNI. Jurnal Aplikasi Bisnis Dan Manajemen (JABM), 4(1).

Setyono, L. (2015). The effect of Islamic marketing and corporate image on customer satisfaction and customer loyalty (Study on customers of PT Bank Muamalat Indonesia Malang branch office). Jurnal Administrasi Bisnis (JAB), 27(1).

Sri rahayu, B., Saryanti, E., \& STIE Adi Unggul Bhirawa Surakarta. (2014). Pengaruh Kualitas Pelayanan, Hubungan Pelanggan Dan Citra Perusahaan Terhadap Loyalitas Melalui Kepuasan Nasabah. ADVANCE, 1(2).

Suryani, \& Hendriyadi, H. (2016). Metode riset kuantitatif: Teori dan aplikasi pada penelitian bidang manajemen dan ekonomi Islam. Prenada Media.

Suwitho, M. (2014). Pengaruh Customer Relationship Management Terhadap. Jurnal IImu Dan Riset Manajemen, 3.

Trisnowati, J. (2012). Pengaruh Kualitas Pelayanan Terhadap Kepuasan Nasabah Di PT. Bank Perkreditan Rakyat Kartasura Saribumi Cabang Masaran.

Yudiana, F. E., \& Setyono, J. (2016). Analisis Corporate Social Responsibility, Loyalitas Nasabah, Corporate Image dan Kepuasan Nasabah pada Perbankan Syariah. INFERENSI: Jurnal Penelitian Sosial Keagamaan, 10(1), 93-114.

Yulimindra, I., \& Samsir, G. W. (2015). Pengaruh Kualitas Layanan dan Inovasi Terhadap Citra Perusahaan dan Loyalitas Nasaba pada PT Bank Riau Kepri. Jurnal Tepak Manajemen Bisnis, 7(3).

Apriyanti, P., Surya, D., \& Lutfi, L. (2017). Analisis Kualitas Layanan Dan Citra Perusahaan Terhadap Loyalitas Nasabah Dengan Kepuasan Nasabah Sebagai Variabel Intervening (Studi Empirik Nasabah Tabungan Tandamata Bank BJB Cabang Serang). Jurnal Riset Bisnis Dan Manajemen Tirtayasa, 1(2).

Bawono, A. (2006). Multivariate analysis dengan SPSS. Salatiga: STAIN Salatiga Press.

Ghozali, I. (2018). Aplikasi Analisis Multivariate dengan Program IBM SPSS 25 (9th ed.). Semarang: Semarang: Badan Penerbit Universitas Diponegoro.

Goyena, R., \& Fallis, A. . (2019). Statistik Perbankan Syariah - Desember. Journal of Chemical Information and Modeling, 53(9), 1689-1699.

Haryono, S., Hilman, I., \& Mughits, A. (2003). Perbankan Syariah Masa Depan. Jakarta: Senayan Abadi Publishing.

Imasari, K., \& Nursalin, K. K. (2011). Pengaruh Customer Relationship Management terhadap Loyalitas Pelanggan pada PTBCA Tbk. Fokus Ekonomi (FE), 10(3). 
Ishak, M. Z., \& Azzahroh, E. P. (2017). Pengaruh Kualitas Layanan Terhadap Loyalitas Nasabah Bank Syariah Dengan Kepuasan Nasabah Sebagai Variabel Intervening. Jurnal Ekonomi Dan Bisnis Islam (Journal of Islamic Economics and Business), 3(1). https://doi.org/10.20473/jebis.v3i1.3599

Komalasari, E. (2015). Peranan Customer Relationship Dalam Meningkatkan Loyalitas Nasabah Di PerBankan. Peranan Customer Relationship Dalam Meningkatkan Loyalitas Nasabah Di Perbankan, 9(2).

Kotler, P., Keller, \& Lane, K. (2012). Manajemen Pemasaran (Jilid 2). Jakarta: PT. Indeks.

Lutfiana, A. A., Saryadi, S., \& Wijayanto, A. (2013). Pengaruh citra Merek dan Kualitas Produk Dengan Kepuasan Konsumen Sebagai Variabel Antara Terhadap Loyalitas Konsumen Air Minum Merek Aqua (Studi pada Konsumen Aqua yang Berdomisili di Perumahan Puri Anjasmoro). Jurnal Ilmu Administrasi Bisnis, 1(1), 61-72.

Mulyaningsih, L. A., \& Suasana, I. (2016). Pengaruh Kualitas Layanan Dan Citra Perusahaan Terhadap Kepuasan Nasabah Pada Bank Ocbc Nisp Di Denpasar. E-Jurnal Manajemen Universitas Udayana, 5(1).

Nardiman. (2017). Pengaruh Customer Relationship Management Dan Customer Value Terhadap Kepuasan Nasabah Dan Dampaknya Pada Loyalitas Nasabah Bank BRI Unit Tiku Cabang Bukittinggi. Jurnal EKOBISTEK Fakultas Ekonomi, 6(2), 251-256.

Nisazizah, B., \& Sudaryanto, B. (2018). Analisis Pengaruh Kualitas Layanan, Nilai Nasabah, dan Customer Relationship Management terhadap Kepuasan Nasabah Serta Loyalitas Nasabah (Studi Pada Nasabah BNI Syariah Kantor Cabang Semarang dan Kantor Cabang Pembantu UNISULA). Diponegoro Journal of Management, 7(4), 116-127.

Rhenald, K. (2003). Marketing Public Relations. Jakarta: PT Temprint.

Riduwan, \& Akdon. (2013). Rumus Dan Data Dalam Analisis Statistika. Bandung: Alphabeta.

Saputra, R. Ben, \& Alwie, A. P. (2015). Pengaruh Kualitas Pelayanan dan Kepuasan Nasabah Terhadap Loyalitas Nasabah Pada PT. Bank Riau Kepri cabang Siak. Jurnal Tepak Manajemen Bisnis, 7(2), 285-294.

Saputra, F. I. (2013). Kualitas Layanan, Citra dan Pengaruhnya terhadapLoyalitas melalui Kepuasan Pelanggan(Studi Pada PT Bank Bni 46 Sentra Kredit Kecil Surabaya). JURNAL APLIKASI MANAJEMEN, 2(3).

Sari, N. P., Daryanto, H. K., \& Saptono, I. T. (2018). Pengaruh customer relationship management terhadap kepuasan dan loyalitas nasabah PT Bank BNI. Jurnal Aplikasi Bisnis Dan Manajemen (JABM), 4(1).

Setyono, L. (2015). The effect of Islamic marketing and corporate image on customer satisfaction and customer loyalty (Study on customers of PT Bank Muamalat Indonesia Malang branch office). Jurnal Administrasi Bisnis (JAB), 27(1).

Sri rahayu, B., Saryanti, E., \& STIE Adi Unggul Bhirawa Surakarta. (2014). Pengaruh Kualitas Pelayanan, Hubungan Pelanggan Dan Citra Perusahaan Terhadap Loyalitas Melalui Kepuasan Nasabah. ADVANCE, 1(2). 
Suryani, \& Hendriyadi, H. (2016). Metode riset kuantitatif: Teori dan aplikasi pada penelitian bidang manajemen dan ekonomi Islam. Prenada Media.

Suwitho, M. (2014). Pengaruh Customer Relationship Management Terhadap. Jurnal IImu Dan Riset Manajemen, 3.

Trisnowati, J. (2012). Pengaruh Kualitas Pelayanan Terhadap Kepuasan Nasabah Di PT. Bank Perkreditan Rakyat Kartasura Saribumi Cabang Masaran.

Yudiana, F. E., \& Setyono, J. (2016). Analisis Corporate Social Responsibility, Loyalitas Nasabah, Corporate Image dan Kepuasan Nasabah pada Perbankan Syariah. INFERENSI: Jurnal Penelitian Sosial Keagamaan, 10(1), 93-114.

Yulimindra, I., \& Samsir, G. W. (2015). Pengaruh Kualitas Layanan dan Inovasi Terhadap Citra Perusahaan dan Loyalitas Nasaba pada PT Bank Riau Kepri. Jurnal Tepak Manajemen Bisnis, 7(3). 